\title{
De social defeat-hypothese
}

\author{
Citation for published version (APA):
}

Selten, J. P. (2012). De social defeat-hypothese. Maastricht University. https://doi.org/10.26481/spe.20121116js

Document status and date:

Published: 16/11/2012

DOI:

10.26481/spe.20121116js

Document Version:

Publisher's PDF, also known as Version of record

\section{Please check the document version of this publication:}

- A submitted manuscript is the version of the article upon submission and before peer-review. There can be important differences between the submitted version and the official published version of record.

People interested in the research are advised to contact the author for the final version of the publication, or visit the DOI to the publisher's website.

- The final author version and the galley proof are versions of the publication after peer review.

- The final published version features the final layout of the paper including the volume, issue and page numbers.

Link to publication

\footnotetext{
General rights rights.

- You may freely distribute the URL identifying the publication in the public portal. please follow below link for the End User Agreement:

www.umlib.nl/taverne-license

Take down policy

If you believe that this document breaches copyright please contact us at:

repository@maastrichtuniversity.nl

providing details and we will investigate your claim.
}

Copyright and moral rights for the publications made accessible in the public portal are retained by the authors and/or other copyright owners and it is a condition of accessing publications that users recognise and abide by the legal requirements associated with these

- Users may download and print one copy of any publication from the public portal for the purpose of private study or research.

- You may not further distribute the material or use it for any profit-making activity or commercial gain

If the publication is distributed under the terms of Article $25 \mathrm{fa}$ of the Dutch Copyright Act, indicated by the "Taverne" license above, 
1) Maastricht University

Prof. dr. J.P Selten

School for Mental Health and Neuroscience FHML

\section{Inaugurale rede}

\section{De Social Defeat-hypothese}


De Social Defeat-hypothese 



\section{De Social Defeat-hypothese}

\section{Rede}

Uitgesproken bij de aanvaarding van het bijzonder hoogleraarschap Sociale Exclusie en Psychiatrische Stoornissen aan de Universiteit Maastricht.

Maastricht 16 november 2012

Prof.dr. J.P. Selten 



\section{De Social Defeat-hypothese}

\section{Inleiding}

Mijnheer de rector magnificus, waarde collega's, lieve familieleden en vrienden, zeer gewaardeerde toehoorders,

In de eerste plaats wil ik $\mathrm{u}$ hartelijk welkom heten en zeggen hoezeer ik het waardeer dat $u$ vandaag in zo grote getale bent gekomen. Het is de meesten van $u$ bekend dat de afdeling psychiatrie en psychologie van deze universiteit onderzoek verricht naar de oorzaken van psychotische stoornissen. In de komende 45 minuten zal ik bepleiten dat de positie van buitenstaander en verliezer hier een belangrijke oorzaak van is. Deze stelling staat inmiddels bekend als de social defeat-hypothese. Het eerste deel van mijn betoog gaat over de totstandkoming van deze hypothese. In het tweede deel vertel ik wat we gaan doen om deze hypothese te toetsen.

Maar voor ik van start ga moet ik u iets uitleggen over de twee soorten psychosen die psychiaters in hun dagelijks werk onderscheiden. In de eerste plaats kennen we de manisch-depressieve psychose. De patiënt met deze stoornis wordt geplaagd door depressies, soms afgewisseld met manieën. Tijdens een depressieve of manische periode is de realiteitszin vaak gestoord. De depressieve patiënt kan er bijvoorbeeld van overtuigd zijn dat hij kanker heeft en de manische patiënt kan denken dat hij president van Amerika is. De manisch-depressieve psychose zou je dus ook de stemmingsgebonden psychose kunnen noemen. Daarnaast kennen we de niet-stemmingsgebonden psychose, die ook optreedt als de stemming niet duidelijk gestoord is. Patiënten met deze psychose denken dat er op tv over hen wordt gepraat of dat ze worden afgeluisterd door een geheime dienst. Soms horen ze stemmen van niet-aanwezige personen. Hun stemming is daarbij soms wel gedrukt of angstig, maar meestal niet uitgesproken depressief of 
uitgelaten. Als deze psychose ernstig is en langdurig spreken we van schizofrenie. Mijn verhaal gaat over deze tweede vorm van psychose, waar wereldwijd ongeveer 50 miljoen mensen aan lijden. Om het kort te houden en de term "niet-stemmingsgebonden psychose" te vermijden zal ik het vaak hebben over psychose of psychotische stoornis. Dan bedoel ik dus de niet-stemmingsgebonden psychose. 


\section{De Social Defeat-hypothese}

We weten dat zowel erfelijke als niet-erfelijke oorzaken bij het ontstaan van deze niet-stemmingsgebonden psychosen een rol spelen, maar over de aard van die erfelijke oorzaken weten we nog betrekkelijk weinig. In de afgelopen jaren is het duidelijk geworden dat er honderden en misschien wel duizenden genen bij betrokken zijn en dat de bijdrage van ieder gen afzonderlijk klein is (van Os et al., 2010). Niemand weet eigenlijk waarom er zoveel genen bij betrokken zijn.

Behalve van die genen weten we van een aantal andere factoren dat ze het risico op de stoornis verhogen. De belangrijkste vijf zijn opgroeien in een stedelijke omgeving, een laag IQ, traumatische ervaringen in de jeugd, druggebruik en een voorgeschiedenis van migratie. Ik loop ze alle vijf even langs. In het algemeen geldt: hoe groter de stad waarin je opgroeit, hoe hoger het risico (Pedersen \& Mortensen, 2001). Om u een idee te geven: personen die opgroeien in steden als Amsterdam of Kopenhagen hebben een drie keer zo hoog risico als personen die opgroeien op het platteland. Voor personen die opgroeien in kleinere steden, zoals Leiden of Maastricht, is het risico minder verhoogd en ongeveer 2 keer zo hoog. Voor intelligentie geldt: hoe lager de intelligentie, hoe hoger het risico. Als je het risico vergelijkt voor personen met een laag-gemiddeld IQ van 80-95 met het risico voor personen met een hoog IQ, van 125 of meer, dan is het risico voor de personen met het laag-gemiddelde IQ ongeveer 3 tot 4 keer zo hoog (David et al., 1997; Zammit et al., 2004). Met een trauma in de jeugd bedoelen we seksueel misbruik, geestelijke of lichame-lijke mishandeling, verwaarlozing, overlijden van een ouder of intensief gepest worden door leeftijdsgenoten. Het risico voor personen die rapporteren dat ze dit hebben meegemaakt is gemiddeld twee tot drie keer zo hoog (Cutajar et al., 2010; van Dam et al., 2012; Varese et al., 2012). Het effect van drugs is afhankelijk van de gebruikte substantie en de frequentie en duur van het gebruik. Dagelijks gebruik van amfetamine of een hoog- 
potent cannabisproduct is geassocieerd met een hoog risico op psychose (Chen et al., 2003; Henquet et al., 2005; Diforti et al., 2009). Het risico voor migranten is hoger dan voor autochtonen en varieert sterk per etnische groep (Cantor-Graae \& Selten, 2005; Bourque et al., 2011). Voor African-Caribbeans in Engeland, afkomstig uit Jamaica, Barbados of Trinidad, is het risico in sommige onderzoeken wel 9 keer hoger dan voor autochtone Britten (Fearon et al., 2006; Coid et al., 2008; zie ook Selten et al., 2012). Als u deze opsomming hoort, vraagt u zich wellicht af hoe dit ons verder helpt. De meeste personen met een laag IQ worden niet psychotisch en hetzelfde geldt voor stadsbewoners en migranten.

\section{William van Ockham (1288-1347)}

Dit is het moment om $u$ voor te stellen aan William van Ockham, een Franciscaner monnik en filosoof uit de 14 e eeuw, die beroemd is geworden door zijn stelling dat je in de wetenschap spaarzaam moet zijn met je aannames. Hij zei dat als je een poging doet om iets te verklaren je zo min mogelijk moet speculeren. Dit principe staat in de wetenschapsfilosofie bekend als het scheermes van Ockham. De functie van het scheermes is het wegsnijden van alle overbodige aannames. Als we het principe van Ockham toepassen op de vijf omgevingsfactoren die een rol spelen bij het ontstaan van psychosen, dan zullen we dus moeten onderzoeken of we die vijf factoren kunnen terugbrengen tot één of twee gemeenschappelijke factoren. Dat is geen eenvoudige opgave. Om dat te kunnen doen moeten we meer begrijpen van context en betekenis.

\section{Migranten}

Het aardige is nu dat het patroon van bevindingen bij migranten ons op weg helpt. Dat patroon ziet er als volgt uit. In de eerste plaats is het risico voor allochtonen van de tweede generatie even sterk verhoogd als voor allochtonen van de eerste generatie (Bourque et al., 2011). De reis is dus niet de kritische factor, maar het lidmaatschap van een etnische minderheid. Ten tweede is het risico voor migranten uit ontwikkelingslanden hoger dan dat voor migranten uit ontwikkelde landen. Voor 
migranten uit ontwikkelingslanden is het risico gemiddeld 3 keer zo hoog. Voor migranten uit ontwikkelde landen twee keer zo hoog (Cantor-Graae \& Selten, 2005). Ten derde geldt: huidskleur speelt een rol. Personen met een zwarte huidskleur hebben in Europa een gemiddeld vijf keer zo hoog risico als autochtonen (Cantor-Graae \& Selten, 2005). Onderzoeken in de landen van herkomst, zoals Suriname, Jamaica, Barbados en Trinidad, toonden aan dat het risico aldaar niet verhoogd is (Selten et al., 2005; Mahy et al., 1999). Overigens, migranten met een zwarte huidskleur hebben niet overal de hoogste risico's. De hoogste risico's worden gevonden voor de groepen die het minst succesvol integreren. In Nederland zijn dat de Marokkaanse mannen (Selten et al., 2001; Veling et al., 2006). In Engeland de African-Caribbeans en Afrikanen afkomstig uit het gebied ten zuiden van de Sahara (van Os et al., 1996; Fearon et al., 2006). In Denemarken de autochtone bewoners van Groenland, ook wel Eskimo's of Inuït geheten (Cantor-Graae \& Pedersen, 2007). Er zijn ook aanwijzingen voor beschermende factoren. Want een vijfde consistente bevinding houdt in dat het risico minder verhoogd is voor groepen die bekend staan om hun sterke familiebanden, zoals Aziaten in Engeland en Turken van de eerste generatie in Nederland (Selten \& Sijben, 1994; Fearon et al., 2006; Coid et al., 2008). Een zesde bevinding, tenslotte, betreft de invloed van de samenstelling van de wijk. Het risico is namelijk minder hoog voor migranten die met grote aantallen in dezelfde wijk wonen. Dit is eerst gevonden in New York en Londen (Boydell et al., 2001) en later ook in Den Haag. Collega Wim Veling constateerde dat het risico voor Surinamers in Transvaal of Schilderswijk, waar veel Surinamers wonen, lager was dan voor Surinamers in wijken met weinig Surinamers. Hetzelfde gold voor Turken en Marokkanen in de stad (Veling et al., 2008). Dit wordt wel het beschermend effect van etnische dichtheid genoemd.

\section{Buitenstaanders en verliezers}

Als we de feiten op een rij zetten: hoge cijfers voor migranten uit ontwikkelingslanden, vooral als de integratie moeizaam verloopt, en een beschermend effect van familiebanden of samen in een wijk 
wonen, dan is het niet helemaal vreemd om te veronderstellen dat de positie van buitenstaander, en dus ook van verliezer, ten grondslag ligt aan deze bevindingen. Veel migranten uit ontwikkelingslanden krijgen geen toegang tot onze maatschappij of slagen er niet in om zich deze toegang te verwerven. Ze krijgen de minder aantrekkelijke banen of blijven werkloos. Hun kinderen, in Nederland geboren, krijgen ook vaak het gevoel dat ze slechts buitenstaanders zijn. De journalist Anil Ramdas beschreef het als volgt: "Wij willen westerlingen zijn, Nederlanders zelfs, maar tot ver in deze eeuw zullen we worden buitengesloten als niet-westerlingen, als allochtonen, als buitenstaanders" (geciteerd door Frits Abrahams, NRC Handelsblad, 20 februari 2012).

Is de positie van buitenstaander of verliezer mogelijk ook van toepassing op de andere vier omgevingsfactoren voor psychosen: opgroeien in een stad, laag $\mathrm{IQ}$, traumatische ervaringen in de jeugd en druggebruik? Opgroeien in de stad betekent deelname aan meer competitie. ledereen die in Nederland wel eens de Maas of de IJssel oversteekt weet dat. Hoe groter de stad, hoe meer competitie. Is de competitie feller, dan komen nederlagen harder aan, ook omdat stedelingen minder stevig sociaal zijn ingebed dan bewoners van dorpen, waar iedereen elkaar kent. Dat personen met een laag IQ buitenstaanders en verliezers zijn behoeft weinig betoog. Geen enkele werkgever wil iemand met een IQ van 75 en de huidige regering doet er graag nog een schepje boven op door te bezuinigen op de sociale werkplaatsen. Traumatische ervaringen in de jeugd variëren van gepest worden op school en verwaarlo-zing door de ouders tot geestelijke of lichamelijke mishandeling. Welnu, gepest worden is zo pijnlijk omdat je wordt buitengesloten. Wij zijn groepsdieren en verstoting uit de groep is voor ons daarom extreem bedreigend en pijnlijk (de Waal, 2009; Eisenberger, 2012). Verwaarloosde en misbruikte kinderen voelen zich buitenstaanders en verliezers, omdat zij niet ontvangen wat hun leeftijdsgenoten wel krijgen. Bovendien ontwikkelen zij vrijwel altijd een psychiatrische stoornis, waardoor dit gevoel nog eens versterkt wordt. Hoe staat het met de risicofactor druggebruik? Druggebruikers zijn 
vaak buitenstaanders en verliezers, maar het is niet aannemelijk dat ze door deze positie in de maatschappij psychotisch worden. Dat zal toch eerder komen door de inwerking van een giftige stof. Aan de andere kant geldt dat traumatische ervaringen in de jeugd een belangrijke oorzaak vormen van een latere verslaving (Stewart, 1996; Simpson et al., 2002). In zoverre past druggebruik weer wel in deze rij.

\section{Social defeat-hypothese}

De vraag of de positie van buitenstaander en verliezer wellicht ook van toepassing is op de andere omgevingsfactoren voor psychosen kunnen we dus positief beantwoorden. Daarom publiceerden Liza CantorGraae en ik 7 jaar geleden de zogenaamde social defeat-hypothese, die inhoudt dat de langdurige, subjectieve ervaring een buitenstaander of verliezer te zijn de dopamine-huishouding in het brein ontregelt en daardoor het risico op een psychose verhoogt (Selten \& Cantor-Graae, 2005; 2007). Uit onderzoek blijkt dat tientallen stoffen in het brein betrokken zijn bij de reactie op nederlagen. Vanwaar die nadruk op dopamine? Een verhoogde afgifte van dopamine leidt tot een psychose en alle medicamenten tegen psychose blokkeren de receptoren in het brein waar dopamine op aangrijpt (Laruelle, 2003; Kapur, 2003). Dus, mocht $u$ zich ooit hebben afgevraagd wat psychiaters de hele dag doen, dan heeft $u$ hier het antwoord: zij blokkeren dopaminereceptoren. De grote vraag voor onderzoekers luidt: wat is de oorzaak van de verhoogde afgifte van dopamine? Welnu, meerdere experimenten met proefdieren hebben aangetoond dat nederlagen van invloed zijn op de afgifte van deze stof.

\section{Dierexperiment}

Het meest markante experiment is dat van de verslagen binnendringer. Een mannelijk rat bewoont een kooi. Dat is zijn territorium. De onderzoeker plaatst vervolgens een andere mannelijke rat, die wat kleiner is, in deze kooi. De bewoner valt de binnendringer binnen enkele seconden aan en dwingt hem tot overgave. De onderzoeker haalt de verslagen binnendringer vervolgens uit de kooi. Deze procedure 
wordt enkele malen herhaald met tussenpozen van een week. Na enkele weken beschik je dus over een rat die herhaaldelijk verslagen is. Je kunt vervolgens het dopaminesysteem van de verslagen rat testen door toediening van amfetamine, een stof die de afgifte van dopamine stimuleert. De verslagen rat reageert hier overdreven op, veel heftiger dan andere ratten. Met andere woorden: zijn dopaminesysteem is ontregeld geraakt en overgevoelig geworden voor stimulatie door amfetamine (Tidey \& Miczek, 1996; Covington \& Miczek, 2001; zie ook Morgan et al., 2002). Hetzelfde zien we bij onze psychotische patiënten. Als zij gestimuleerd worden met amfetaminen reageren ze daar veel heftiger op dan andere personen (Laruelle, 2003). Onze patiënten lijken dus in bepaalde opzichten op verslagen dieren.

\section{Social defeat}

De stress van social defeat verschilt van andere vormen van stress, zoals armoede, honger, ziekte en oorlog. Denkt u maar aan de Somaliër uit Mogadishu, die, eenmaal ontsnapt aan de gevaren in Afrika, in Nederland geconfronteerd wordt met een heel andere uitdaging: hoe verwerf ik me als zwarte Somaliër een positie in de Nederlandse maatschappij? De social defeat-hypothese stelt dat deze vorm van stress, in combinatie met een erfelijke aanleg, een psychotische stoornis kan veroorzaken. Die erfelijke aanleg is belangrijk: sommige personen zijn door hun erfelijke aanleg gevoeliger voor deze vorm van stress dan anderen. In ons vak spreken we dan van een gen-omgevings interactie.

Ik denk overigens niet dat de ervaring van social defeat een noodzakelijke voorwaarde is voor het ontstaan van psychosen. Social defeat is één van de factoren die het ontstaan van een psychose bevorderen, maar niet de enige. Je kunt dus ook psychotisch worden door andere oorzaken, zoals druggebruik of een grote erfelijke belasting.

De social defeat-hypothese stelt dat het gaat om de subjectieve ervaring een buitenstaander of verliezer te zijn. Waarom subjectief? Het antwoord luidt dat de objectieve situatie vaak weinig zegt over hoe ie- 
mand zich voelt. Dat behoeft niet zo veel betoog. We kennen allemaal gefrustreerde hoogleraren en trotse buschauffeurs. Ik herinner u ook aan het effect van etnische dichtheid. Het voelt heel anders om werkloos te zijn in een buurt waar iedereen werkloos is dan in een buurt waar niemand werkloos is. Het gaat om de subjectieve beleving.

\section{Concepten}

$\mathrm{U}$ heeft mij twee begrippen horen bezigen: sociale uitsluiting en social defeat. Wat zijn precies de verschillen en overeenkomsten? Sociale uitsluiting is wel omschreven als een opgelegd gebrek aan sociale, culturele en politieke participatie (Morgan et al., 2007). Social defeat vervolgens hebben we gedefinieerd als de subjectieve ervaring een buitenstaander of verliezer te zijn. De overeenkomsten zijn groot. Het verschil is gelegen in het spanningsveld tussen subjectief en objectief. Het concept sociale uitsluiting benadrukt dat het gebrek aan participatie door derden, van buitenaf, is opgelegd. Het begrip social defeat vestigt de aandacht op de subjectieve beleving. Voor de verdere ontwikkeling van het onderzoek is het belangrijk oog te houden voor beide aspecten.

\section{Genetic confounding?}

In discussies over dit onderwerp is dit meestal het moment waarop de psychiater met een voorkeur voor genetische verklaringen op de proppen komt. Hij is het niet met mij eens. Zijn argument luidt dat patiënten, in de jaren voordat ze psychotisch worden, zich reeds anders gedragen en dat dit gedrag verklaard wordt door genen. Personen met de erfelijke aanleg voor psychose zijn immers sociaal onhandig, blijven eenlingen en worden vervolgens ontevreden over wat ze bereikt hebben. Ze denken vervolgens dat het gras ergens anders groener is en besluiten om te emig-reren. Ze worden psychotisch in het land van bestemming, maar waren dat ook geworden als ze gewoon thuis waren gebleven (Ødegaard, 1932). Deze psychiater stelt dus dat het verband tussen migratie en psychose verklaard wordt door wat in de epidemiologie bekend staat als genetic confounding. De volgorde 
van oorzaak en gevolg is in zijn optiek omgekeerd en de omgevingsfactoren zijn niet van belang. Hij poneert dezelfde verklaringen voor de andere verbanden. Personen met de erfelijke aanleg voor psychose vestigen zich in de stad, omdat ze daar anoniemer kunnen zijn dan op het platteland. Als ze op het platteland waren gebleven waren ze ook psychotisch geworden (Pedersen \& Mortensen, 2006). Personen met de erfelijke aanleg voor psychose hebben veel problemen en gebruiken daarom veel drugs. Als ze de drugs niet hadden gebruikt waren ze ook psychotisch geworden (van Amsterdam, 2004). Tenslotte, personen met de erfelijke aanleg voor psychose hebben geringe sociale vaardigheden en zijn daarom weinig weerbaar. Dientengevolge raken ze in slecht gezelschap en worden ze getraumatiseerd. De relatie tussen laag IQ en psychose, tenslotte, schrijft hij toe aan gemeenschappelijke genen. De genen die verantwoordelijk zijn voor een laag IQ zijn volgens hem ook verantwoordelijk voor het ontstaan van een psychose (Toulopoulou et al., 2007).

Het klinkt op het eerste gezicht niet onaardig wat deze psychiater zegt, want erfelijke factoren beïnvloeden ons gedrag in hoge mate. Maar deze psychiater zegt meer dan dat. Hij zegt dat dezelfde genen die predisponeren voor een psychose ook predisponeren voor emigratie, urbanisatie, druggebruik, traumatisering en laag IQ. Hij heeft tenminste vier problemen. In de eerste plaats kan hij zijn stelling niet onderbouwen met bewijs. Er is bijvoorbeeld geen bewijs dat personen met de erfelijke aanleg voor psychose vaker migreren. Alle gegevens wijzen op het tegendeel. Twee studies uit Denemarken bijvoorbeeld constateerden dat kinderen van psychotische ouders minder vaak emigreren dan andere kinderen (Rosenthal et al., 1974; Pedersen et al., 2011). In de tweede plaats: hij is monomaan en houdt er geen rekening mee dat beide verklaringen tegelijkertijd waar kunnen zijn. Er zijn inderdaad aanwijzingen dat personen met de erfelijke aanleg voor psychose het stedelijk milieu opzoeken (Pedersen \& Mortensen, 2006), maar dat sluit nog niet uit dat dit milieu vervolgens van invloed is op het ontwikkelen van psychiatrische problemen. 
In de derde plaats zijn de aannames tegenstrijdig. Personen met de aanleg voor psychose zouden weinig weerbaar zijn en daarom getraumatiseerd worden, maar migranten zijn juist heel erg weerbaar. Anders heb je niet het lef om te migreren.

Maar zijn grootste probleem is het grote aantal onbewezen aannames. Hij neemt aan dat er genen bestaan die een psychose veroorzaken, maar ook bevorderen dat de dragers van die genen vaker emigreren, in een stad gaan wonen, vaker gepest worden, vaker getraumatiseerd worden en vaker drugs gebruiken. Dat zijn wel veel aannames tegelijk. William van Ockham zou zijn wenkbrauwen fronsen.

De social defeat-hypothese biedt wél een spaarzame verklaring en houdt in dat migratie, urbanisatie, trauma en laag IQ de kans vergroten om in de positie van buitenstaander en verliezer te geraken. In combinatie met een erfelijke aanleg leidt dat tot psychose. Ik kom graag nog even terug op de bewering van de psychiater met een voorkeur voor genetische verklaringen dat de genen voor een laag IQ ook verantwoordelijk zijn voor het ontstaan van een psychose. Uit een recente tweelingstudie in Zweden blijkt dat daar weinig van klopt. De studie liet zien dat laag IQ en psychose slechts 7\% van hun genen delen (Fowler et al. 2012). Dit betekent dat er andere verklaringen moeten zijn voor de sterke relatie tussen IQ en psychose. De social defeat-hypothese biedt een dergelijke verklaring. Het lage IQ, dat hoofdzakelijk door erfelijke factoren wordt bepaald, leidt er toe dat de persoon in een ongunstige omgeving belandt en daardoor een hoog risico loopt op een psychose. In wetenschappelijk Engels heet dat : environmental mediation of a genetic effect.

\section{Andere epidemiologische bevindingen}

Zijn er misschien nog andere epidemiologische bevindingen die onder de noemer van social defeat kunnen vallen? Dat zou de hypothese natuurlijk krachtig ondersteunen. Het antwoord luidt bevestigend. In de eeste plaats zijn daar de verhoogde risico's voor African-Americans. Het 
is enige tijd taboe geweest om over dit onderwerp te publiceren, maar de cijfers van vroeger (Malzberg, 1935; 1965; samengevat in Selten \& Cantor-Graae, 2004) en van de laatste jaren wijzen op een ongeveer drievoudig verhoogd risico (Bresnahan et al., 2007; Gara et al., 2012). Homoseksuelen voelen zich vaak buitenstaanders. Onderzoeken in Engeland (Chakraborty et al., 2011) en Nederland, de laatste afkomstig van onze onderzoeksgroep (Gevonden et al., submitted), vonden tweevoudig verhoogde risico's op psychotische symptomen voor personen met een homoseksuele oriëntatie.

Vervolgens is van een aantal stoornissen bekend dat ze leiden tot sociale uitsluiting en dat ze geassocieerd zijn met een verhoogd risico op psychose. Slechthorendheid op jonge leeftijd is daar een duidelijk voorbeeld van. Jonge slechthorenden zijn buitenstaanders en hun risico op psychose is verhoogd (David et al., 1995; Stefanis et al., 2006; van der Werf et al., 2011). Ouderen die doof worden zijn door hun leeftijd beschermd tegen het ontwikkelen van een psychose, maar achterdochtig worden ze wel. In de tweede plaats personen met een autistische stoornis. Er is weinig onderzoek gedaan naar het voorkomen van psychosen bij hen, maar het beschikbare onderzoek wijst op een sterk verhoogd risico (Hofvander et al., 2009; Howlin et al., 2009; Mukaddes et al., 2010). U hoort mij niet zeggen dat sociale uitsluiting de enige verklaring daarvoor is. Wel dat uitsluiting aan dit verhoogde risico bijdraagt. Mannen met het syndroom van Klinefelter hebben een extra Xchromosoom en kleine geslachtsorganen en zijn onvruchtbaar (Bojesen et al., 2006; Bruining et al., 2009). Hun risico's zijn 6-8 keer verhoogd. En tenslotte personen met een gender identiteitsstoornis. Jongens die zich een meisje voelen en meisjes die zich een jongen voelen. Er zijn aanwijzingen dat zij een hoog risico lopen om later een psychotische stoornis te ontwikkelen, maar betrouwbare cijfers zijn er niet (à Campo et al., 2003).

\section{Specifiek?}

U vraagt zich wellicht af of de stress van social defeat ook een oorzaak is van andere psychiatrische stoornissen. Het antwoord hierop luidt: voor 
sommige stoornissen wel, voor andere niet. Als we de literatuur overzien, dan is de stress van social defeat inderdaad een risicofactor voor het ontstaan van depressie en verslaving, maar in veel mindere mate van de manisch-depressieve psychose. Een laag IQ of opgroeien in de stad vormen immers geen risicofactor voor het ontwikkelen van een manisch-depressieve psychose (Pedersen \& Mortensen, 2006) en van migratie is het nog niet duidelijk (Swinnen \& Selten, 2007).

Als social defeat een oorzaak is van meerdere psychiatrische stoornissen, verzwakt dat dan de hypothese? Ik meen van niet. Het komt in de geneeskunde wel vaker voor dat een bepaalde oorzaak niet specifiek is voor één aandoening. Het roken van sigaretten bijvoorbeeld is een oorzaak van kanker, atherosclerose, hoge bloeddruk, longziekten, miskramen en wiegendood. Dat doet niks af aan het belang van de sigaretten. Het is dus aannemelijk dat social defeat een risicofactor is voor meerdere psychiatrische stoornissen en dat andere factoren vervolgens beslissen of men een depressie, een verslaving, een psychose of iets anders krijgt.

Het is uiteraard een grote uitdaging om die "andere factoren" te achterhalen. Zijn dat erfelijke of psychologische mechanismen? Het ziet er naar uit dat het type verklaring dat men geeft voor het eigen falen van belang is. Personen die geneigd zijn om de oorzaken van hun falen bij zichzelf te zoeken worden eerder depressief. Personen die deze oorzaken buiten zichzelf plaatsen worden eerder achterdochtig (Blackwood et al., 2001; Bentall et al., 2001). Het slechte functioneren is dan niet hun schuld, want ze worden tegengewerkt. Ik vermoed dat veel buitenstaanders en verliezers hun falen aan externe factoren toeschrijven, omdat zij het zich niet kunnen permitteren om zichzelf nog eens kritisch te onderzoeken. Daar is hun positie te zwak voor.

I $\mathrm{k}$ vat het voorgaande samen. We hebben gezien dat er een consistent en krachtig verband bestaat tussen de positie van buitenstaander en verliezer en het risico op een niet-stemmingsgebonden psychose. $\mathrm{Er}$ is tevens sprake van een duidelijke dosis-respons relatie. Voor stadsbe- 
woners geldt: hoe groter de stad, hoe hoger het risico. Voor migranten: hoe slechter de integratie, hoe hoger het risico. Voor getraumatiseerde personen geldt: hoe ernstiger het trauma, hoe hoger het risico. Voor intelligentie geldt: hoe lager het IQ, hoe hoger het risico. De hypothese biedt een verklaring waarom duizenden genen geassocieerd zijn met een verhoogd risico op psychose, want elke verandering in een gen dat iemand meer of minder getalenteerd, aantrekkelijk of kansrijk maakt, is van invloed op het risico op psychose.

Helaas beschik ik niet over de tijd om in te gaan op de politieke consequenties van de hypothese en de mogelijkheden voor preventie. Ik wil wel opmerken dat we door neoliberale pleidooien voor marktwerking en zelfredzaamheid bijna waren vergeten wie wij zijn. Gelukkig weten we dankzij het werk van Frans de Waal weer dat we niet alleen egoïstisch en agressief zijn, maar ook van nature geneigd tot samenwerken en empathie (de Waal, 2009). Ik stap over naar het tweede deel van mijn verhaal: hoe gaan we de hypothese toetsen en ongetwijfeld ook bijstellen en verder ontwikkelen? 


\section{Toetsing hypothese}

Vanwege de tijd moet ik me hier beperken tot de drie belangrijkste onderzoeken die thans in uitvoering zijn.

\section{Neuroreceptor imaging}

In de eerste plaats willen we natuurlijk onderzoeken of sociale uitsluiting behalve bij dieren ook bij mensen tot een verhoogde afgifte van dopamine leidt. Daarom heb ik samenwerking gezocht met de Hooggeleerde Jan Booij, nucleair geneeskundige in het AMC in Amsterdam. De afgifte van dopamine in de hersenen kun je namelijk niet bepalen door bloed af te nemen uit een arm, maar je hebt daar een bepaalde scanner voor nodig. We hebben na rijp beraad besloten om ons te richten op jonge volwassenen met een verworven slechthorendheid. Door hun handicap zijn ze buitenstaanders en omdat ze niet doof zijn geboren hebben ze een verlieservaring doorgemaakt. We onderzoeken of het brein van deze gezonde slechthorenden, zonder een psychiatrische stoornis, meer dopamine afgeeft dan het brein van normaalhorende leeftijdsgenoten. Bovendien kijken we of het brein van slechthorenden sterker reageert op stimulatie van het dopaminesysteem door toediening van amfetamine. Als je het vergelijkt met cardiovasculaire aandoeningen is het alsof je een groep van dertigjarige rokers die geen hartklachten hebben onderzoekt, en kijkt of ze al vaatafwijkingen hebben. Het bleek niet eenvoudig om jonge slechthorenden te vinden die ook nog in een scanner willen stappen. Maar we hebben nu 15 slechthorenden en 15 normaal horende proefpersonen hiertoe bereid gevonden en zijn erg benieuwd naar de eerste resultaten.

\section{Experience Sampling}

Bij uitleg van de hypothese aan sommige collega's, krijg ik binnen 2 milliseconden de vraag: "Social defeat, kun je dat meten?" Inderdaad, het is in de wetenschap handig als je iets kunt meten. We moeten ons ook realiseren dat het wel eens niet zo eenvoudig zou kunnen zijn 
om de subjectieve beleving van social defeat te meten, want mensen praten niet graag over vernederende ervaringen. We moeten er zelfs rekening mee houden dat die ervaringen bij sommige personen niet bewust zijn. In mijn ervaring kan een enkele patiënt er over praten, de meesten echter niet. Dat is waarschijnlijk ook de reden waarom het zo lang geduurd heeft voordat de hypothese geformuleerd werd en waarom de hypothese op epidemiologisch onderzoek gebaseerd is, niet op verhalen uit de spreekkamer. Het is ondraaglijk om irrelevant te zijn.

Het is dus maar de vraag of je social defeat kunt meten met vragenlijsten, waarop personen moeten rapporteren hoe ze over zichzelf en over anderen denken. Het is aannemelijk dat sommige proefpersonen op dergelijke lijsten geen problemen rapporteren.

Het aardige is nu dat collega's van de Universiteit Maastricht (ik denk daarbij vooral aan Philippe Delespaul, Jim van Os en Inez Germeys) een alternatieve methode hebben ontwikkeld om belevingen in het dagelijks leven te meten, de Experience Sampling Method, afgekort ESM. De proefpersoon die deelneemt aan een ESM-onderzoek draagt een apparaatje op zak, zo groot als een mobiele telefoon, dat op 10 willekeurige momenten per dag een piep afgeeft. De proefpersoon krijgt dan een serie te beantwoorden vragen op het beeldscherm, onder meer over zijn bezigheden, zoals werken, boodschappen doen of sporten, het gezelschap waarin hij verkeert, zijn waardering van dit gezelschap en eventuele problemen, zoals somberheid, eenzaamheid en achterdocht. Het is gebleken dat deze methode vaak meer valide informatie oplevert dan de gebruikelijke vragenlijsten (Myin-Germeys et al., 2011).

Welnu, we gaan een ESM-onderzoek uitvoeren bij 4 groepen deelnemers: autochtone jonge mannen, Marokkaanse jonge mannen, broers van autochtone patiënten met een psychotische stoornis en broers van Marokkaanse patiënten. We hopen op deze manier een antwoord te krijgen op de volgende vragen: 1. Zijn Marokkaanse mannen gevoeliger voor sociale stress dan autochtone mannen? 2. Is erfelijke belasting 
hier van invloed op? We verwachten dat broers van patiënten sterker reageren dan andere personen en dat de broers van Marokkaanse patiënten het heftigst reageren .

We doen bij dezelfde proefpersonen nog een test om te onderzoeken hoe zij reageren op een afwijzing. Deze test, ontwikkeld door Ruud van Winkel en Marieke Wichers, is reeds met succes beproefd. We tonen de deelnemers videoclips waarop leeftijdsgenoten zich kort presente-ren en vragen de deelnemers om deze leeftijdsgenoten te beoordelen op onder meer aantrekkelijkheid. De verhalen op deze videoclips zijn verzonnen. Vervolgens vragen we de deelnemers om ook van zichzelf een videoclip te maken. We maken hen wijs dat deze videoclip beoordeeld wordt door dezelfde leeftijdsgenoten.

Aan het eind van het onderzoek vernemen de deelnemers de beoordeling die fake is. Deze is tamelijk negatief. Meteen na de uitslag meten we het stresshormoon cortisol in speeksel en nemen we een vragenlijst af over de stemming. De verwachting is wederom dat broers van patiënten en Marokkaanse deelnemers heftiger reageren dan anderen. Na afloop van dat halve uur vertellen we de deelnemers dat ze voor het lapje zijn gehouden. De onderzoeker vertelt de deelnemer dat de beoordeling tevoren al vaststond, dat iedere deelnemer exact dezelfde beoordeling krijgt en dat die beoordeling in het geheel niet persoonlijk was.

\section{EU-GEI}

De afdeling psychiatrie van de Universiteit Maastricht heeft een Europese subsidie verkregen om onderzoek te verrichten naar de interactie tussen erfelijke aanleg en omgevingsfactoren bij het ontstaan van psychosen. Rivierduinen prijst zich gelukkig dat het deel mag nemen aan dit fraaie onderzoek, EU-GEl geheten. EU-GEl is een afkorting voor European Union Gene Environment Interaction. In Italië, Spanje, Frankrijk, Engeland en Nederland worden 1500 patiënten met een eerste psychose, 700 van hun broers en zussen en 1500 gezonde proefpersonen onderzocht. Dit gebeurt in stedelijke gebieden, zoals wijken van 
Londen, Parijs en Amsterdam, en in landelijke gebieden, zoals het platteland rondom Cambridge, Clermont-Ferrand, Oviedo en Verona en in twee verzorgingsgebieden van Rivierduinen, te weten de Duin- en Bollenstreek en de omgeving van Gouda. Het onderzoek beoogt de vraag te beantwoorden waarom stedelingen en migranten een hoger risico hebben dan plattelandsbewoners en autochtonen. Er wordt bloed afgenomen voor DNA onderzoek en informatie verzameld over meerdere omgevingsfactoren, met een nadruk op traumatische en stressvolle ervaringen in de jeugd en in de volwassenheid. De leidende gedachte is dat erfelijke aanleg de gevoeligheid voor deze omgevingsfactoren bepaalt. Met andere woorden: sommige personen hebben er door hun erfelijke aanleg geen last van. Andere personen gaan door dezelfde stressfactoren ten onder. Wij hopen uiteraard de genen te identificeren die deze verschillen verklaren.

\section{Testosteron en Oxytocine}

In Nederland meten we bij alle proefpersonen ook de bloedspiegels van twee hormonen, testosteron en oxytocine. De redenen hiervoor zijn de volgende. Succes en verlies hebben vooral bij mannen een grote invloed op de testosteronspiegel. Na een overwinning stijgt hij, na een nederlaag daalt hij. Dit is niet alleen gevonden na bokswedstrijden, maar ook na schaakwedstrijden (Bernhardt et al., 1998; Mazur et al., 1992). We verwachten dus bij patiënten een lager testosteron te vinden dan bij hun broers of bij gezonde proefpersonen. Bovendien willen we weten of deze spiegels gerelateerd zijn met traumatische ervaringen in jeugd of volwassenheid. Dat zou steun verlenen aan de social defeat hypothese.

Het hormoon oxytocine bevordert de ontwikkeling van wederzijds vertrouwen, empathie en altruïsme en zou dus kunnen beschermen tegen de negatieve gevolgen van een nederlaag (Insel, 2010). Merkwaardig genoeg is nog nooit door middel van een representatieve steekproef onderzocht of patiënten met een eerste psychose een tekort hebben aan dit hormoon. Kortom, het EU-GEI onderzoek zal veel nieuwe informatie opleveren over de lotgevallen van buitenstaanders en verliezers. 


\section{3}




\section{Dankwoord}

Dames en heren, ik ben gekomen aan het eind van mijn oratie. De Rector Magnificus, de leden van het College van Bestuur en van de Benoemingscommissie dank ik voor het in mij gestelde vertrouwen.

Mijn speciale dank gaat uit naar de Raad van Bestuur van Rivierduinen die deze leerstoel mogelijk heeft gemaakt. Ik dank met name Ron Laport voor zijn loyale steun aan deze onderneming.

Hooggeleerde van Os, beste Jim. Het moet een keer gezegd worden: jij bent de Johan Cruyff onder de Nederlandse psychiaters. Zoals Cruyff in de zestiger en zeventiger jaren alle mannenharten imponeerde met zijn sierlijke, dansende, balletachtige passeerbewegingen- hij excelleerde niet in zijn eentje, maar zorgde ervoor dat alle teamleden beter gingen voetballen- zo heb jij de afdeling in Maastricht ontwikkeld tot een van de beste onderzoekscentra ter wereld. Ik ben je dankbaar voor je inzet voor deze leerstoel.

Hooggeleerde Germeys, beste Inez. Ik bewonder je snelheid en vaardigheid in het bedenken van theoretische en praktische oplossingen. We begrijpen elkaar snel en het is een waar genoegen om met je samen te werken.

De personen aan wie ik de meeste dank verschuldigd ben zijn helaas niet meer onder ons. Mijn overleden ouders Jan Selten en Lies Baggen zouden hier en nu erg trots zijn geweest.

Twee Amsterdamse hoogleraren, Frans de Jonghe en wijlen Piet Kuiper, hebben op inspirerende wijze onderwijs gegeven in psychoanalyse en afweermechanismen. Hun lessen pas ik nog dagelijks toe.

Veel profijt heb ik gehad van samenwerking met of adviezen van col- 
lega's in binnen- en buitenland. Ik noem in alfabetische volgorde Jan Booij, Elizabeth Cantor-Graae, Mark van der Gaag, Lieuwe de Haan, Annemarie van Hulst, Simone Kool, Willem Nolen, Marion Scholten, Iris Sommer, Wim Veling en Frans Verhey, maar er zijn vele anderen die ik wegens tijdgebrek niet kan noemen.

Ik dank Natalie Veen, Jan Dirk Blom en wijlen Wilma Feller voor hun grote inzet voor de Haagse incidentiestudie.

Mariette Weijer en haar collega's van het secretariaat GGZ Leiden, locatie Oegstgeest, leveren een grote bijdrage aan het plezier in het dagelijkse werk. Mijn dochters Berber en Jasmijn doen dat buiten dat werk.

Dankzij Mieke de Vos, tenslotte, is het weer volop zomer in mijn leven. Ik heb gezegd. 


\section{Referenties}

- Abi-Dargham A, Gil R, Krystal J et al (1998). Increased striatal dopamine transmission in schizophrenia: confirmation in a second cohort. American Journal of Psychiatry, 155, 761-767.

. van Amsterdam JGC, Opperhuizen A, van den Brink W (2004). Cannabis als risicofactor van schizofrenie. Tijdschrift voor Psychiatrie, 46, 515-524.

. Bentall RP. Corcoran R, Howard R, Blackwood N, Kinderman P (2001). Persecutory delusions: a review and theoretical integration. Clinical Psychology Review, 21, 1143-1192. Bernhardt PC, Dabbs JM, Fielden JA, Lutter CD (1998). Testosterone changes during vicarious experiences of winning and losing among fans at sporting events. Physiology and Behavior, 65, 59-62.

Blackwood NJ, Howard RJ, Bentall RP, Murray RM (2001). Cognitive neuropsychiatric models of persecutory delusions. American Journal of Psychiatry, 158, 527-539.

Bojesen A, Juul S, Birkebaek NH, Gravholt CH (2006). Morbidity in Klinefelter syndrome: a Danish register study based on hospital discharge diagnoses. Journal of Clinical Endocrinology, 91, 1254-1260.

- Bourque F, van der Ven E, Malla A (2011). A meta-analysis of the risk for psychotic disorders among first-and second-generation immigrants. Psychological Medicine, 41, 897-910.

Boydell J, van Os J, McKenzie K et al. (2001). Incidence of schizophrenia in ethnic minorities in London: ecological study into interactions with environment. BMJ, 323, 1336-1338.

Bresnahan M, Begg MD, Brown A et al. (2007). Race and risk of schizophrenia in a US birth cohort: another example of health disparity? International Journal of Epidemiology, 36, 751-758.

- Bruining H, Swaab H, Kas M, van Engeland H (2009). Psychiatric characteristics in a selfselected sample of boys with Klinefelter syndrome. Pediatrics, 123, e865-870.

à Campo J, Nijman H, Merckelbach H, Evers C (2003). Psychiatric co-morbidity of gender identity disorders: a survey among Dutch psychiatrists. America Journal of Psychiatry, $160,1332-1336$.

. Cantor-Graae E, Selten JP (2005). Schizophrenia and migration: a meta-analysis and review. American Journal of Psychiatry, 161, 12-24.

. Cantor-Graae E, Pedersen CB (2007). Risk of schizophrenia in second-generation immigrants: a Danish population-based cohort study. Psychological Medicine, 37, 485-494. Chakraborty A, McManus S, Brugha TS, Bebbington P, King M (2011). Mental health of the non-heterosexual population of England. British Journal of Psychiatry, 198, 143-148. Chen CK, Lin SK, Sham PC et al. (2003). Pre-morbid characteristics and co-morbidity of methamphetamine users with and without psychosis. Psychological Medicine, 33, 1407-1414.

Coid JW, Kirkbride JB, Barker D et al. (2008). Raised incidence rates of all psychoses among migrant groups: findings from the East London first episode psychosis study. Archives of General Psychiatry, 66, 161. 
. Covington HE, Miczek KA (2001). Repeated social-defeat stress, cocaine or morphine, Effects on behavioral sensitization and intravenous cocaine self-administration binges. Psychopharmacology, 158, 388-198.

. van Dam DS, van der Ven E, Velthorst E, Selten JP, Morgan C, de Haan L (2012). Childhood bullying and the association with psychosis in non-clinical and clinical samples: a review and meta-analysis. Psychological Medicine, 9, 1-12.

. David A, Malberg A, Lewis G, Brandt L, Allebeck P (1995). Are there neurological and sensory risk factors for schizophrenia? Schizophrenia Research, 14, 247-251.

David AS, Malmberg A, Brandt L, Allebeck P, Lewis G (1997). IQ and risk for schizophrenia: a population-based cohort study. Psychological Medicine, 27, 13111323.

DiForti M, Morgan C, Dazzan P et al. (2009). High-potency cannabis and the risk of psychosis. British Journal of Psychiatry, 195, 488-491.

Eisenberger NI (2012). The pain of social disconnection: examining the shared neural underpinnings of physical and social pain. Nature review of Neuroscience, 13, 421-434.

. Fearon P, Kirkbride JB, Morgan C et al. (2006). Incidence of schizophrenia and other psychoses in ethnic minority groups: results from the MRC AESOP Study. Psychological Medicine, 36, 1541-1550.

. Fowler T, Zammit S, Owen MJ, Rasmussen F (2012). A population-based study of shared genetic variation between pre-morbid IQ and psychosis among male twin pairs and sibling pairs from Sweden. Archives of General Psychiatry, 69, 460-466.

. Gara MA, Vega WA, Arndt S, et al. (2012). Influence of patient race and ethnicity on clinical assessment in patients with affective disorders. Archives of General Psychiatry, 69, 593-600.

. Henquet C, Murray R, Linszen D, van Os J (2005). The environment and schizophrenia: the role of cannabis use. Schizophrenia Bulletin, 31, 608-612.

- Hofvander B, Delorme R, Chaste P et al. (2009). Psychiatric and psychosocial problems in adults with normal-intelligence autism spectrum disorder. BMC Psychiatry, 9:35.

Howlin P (2009). Outcome in adult life for more able individuals with autism or Asperger syndrome. Autism, 4, 63-83.

. Insel TR (2010). The challenge of translation in social neuroscience: a review of oxytocin, vasopressin, and affiliative behavior. Neuron, 65, 768-779.

. Kapur S (2003). Psychosis as a state of aberrant salience: a framework linking biology, phenomenology, and pharmacology in schizophrenia. America Journal of Psychiatry, 160, 13-23.

- Laruelle M, Abi-Dargham A, van Dijck CH et al. (1996). Single photon emission computerized tomography imaging of amphetamine-induced dopamine release in drug-free schizophrenic subjects. PNAS, 93, 9235-9240.

. Laruelle M (2003). Dopamine transmission in the schizophrenic brain. Schizophrenia, (eds. S.R. Hirsch \& D. Weinberger), pp. 365-387.

Mahy GE, Mallett R, Leff J, Bhugra D (1999). First-contact incidence rate of schizophrenia on Barbados. British Journal of Psychiatry, 175, 28-33.

. Malzberg B (1935 b). Mental disease among Negroes in New York State. Human Biology, 7, 471-513. 
- Malzberg B (1965). New data on mental disease among Negroes in New York State, 1960-1961. Research Foundation for Mental Hygiene ${ }_{L}$ Albany, NY.

Mazur, A, Booth A, Dabbs JM (1992). Testosterone and chess competition. Social Psychology Quarterly, 55, 70-77.

- Molloy C, Conroy RM, Cotter DR, Cannon M (2011). Is traumatic brain injury a risk factor for schizophrenia? A meta-analysis of case-controlled population-based studies. Schizophrenia Bulletin, 37, 1104-1110.

- Morgan C, Burns T, Fitzpatrick R, Pinfold V, Priebe S (2007). Social exclusion and mental health: conceptual and methodological review. British Journal of Psychiatry, 191, 477-483.

- Morgan D, Grant KA, Gage D, et al (2002). Social dominance in monkeys: dopamine D2 receptors and cocaine self-administration. Nature Neuroscience, 5, 169-174.

Mukaddes NM, Hergüner S, Tanidir C (2010). Psychiatric disorders in individuals with high-functioning autism and Asperger's disorders: similarities and differences. World Journal of Biological Psychiatry, 11, 964-971.

Myin-Germeys I, Birchwood M, Kwapil T (2011). From environment to therapy in psychosis: a real-world momentary assessment approach. Schizophrenia Bulletin, 37, 244-247. Myin-Germeys I, van Os J, Schwartz JE, Stone AA, Delespaul PA (2001). Emotional reactivity to daily life stress in psychosis. Archives of General Psychiatry, 58, 1137-1144.

- $\varnothing$ degaard $\varnothing$ (1932). Emigration and insanity. Acta Psychiatrica et Neurologica Scandinavica, 4, 1-206.

. van Os J, Castle DJ, Takei N, Der G, Murray RM (1996). Psychotic illness in ethnic minorities: clarification from the 1991 census. Psychological Medicine, 26, 203-208. van Os J, Kenis G, Rutten BP (2010). The environment and schizophrenia. Nature, 468, 203-212.

- Pedersen CB, Mortensen PB (2006). Are the cause(s) responsible for urban-rural differences in schizophrenia risk rooted in families or in individuals? American Journal of Epidemiology, 163, 971-978.

Pedersen CB, Mortensen BP (2006). Urbanicity during upbringing and bipolar affective disorder in Denmark. Bipolar Disorders, 8, 242-247.

Pedersen CB, Mortensen BP (2001). Evidence of a dose-response relationship between urbanicity during upbringing and schizophrenia risk. Archives of General Psychiatry, 58, 1039-1046.

. Pedersen CB, Mortensen PB, Cantor-Graae E (2011). Do risk factor for schizophrenia predispose to emigration? Schizophrenia Research, 127, 229-234.

Selten JP, Sijben AES (1994). First admission rates for schizophrenia in immigrants to the Netherlands. The Dutch national register. Social Psychiatry and Psychiatric Epidemiology, 29, 71-77.

Selten JP, Veen N, Feller W et al. (2001). Incidence of psychotic disorder in immigrant groups to The Netherlands. British Journal of Psychiatry, 178, 367-372.

- Selten JP, Cantor-Graae E (2004). Schizophrenia and migration. In: Gattaz W,Häfner $\mathrm{H}$ (Eds.) Search for the causes of schizophrenia, Volume V. Springer \& Steinkopff, Darmstadt, pp.3-25.

. Selten JP, Zeyl EC, Dwarkasing RM, Lumsden V, Kahn RS, van Harten PN (2005). Firstcontact incidence of schizophrenia in Surinam. British Journal of Psychiatry, 186, 74-75. 
- Selten JP, Cantor-Graae E (2005). Social defeat: risk factor for schizophrenia? British Journal of Psychiatry, 187, 101-102.

Selten JP, Cantor-Graae E (2007). Hypothesis: social defeat is a risk factor for schizophrenia. British Journal of Psychiatry, 191 (Suppl. 51), s9-s12.

- Selten JP, Laan W, Kupka R, Smeets HM, van Os J (2012). Risk of treatment for mood disorders and psychotic disorders among migrants and Dutch nationals in Utrecht, the Netherlands. Social Psychiatry and Psychiatric Epidemiology, 47, 271-278.

- Simpson TL, Miller WR (2002). Concomitance between childhood sexual and physical abuse and substance use problems: A review. Clinical Psychology Review, 22, 27-77.

. Stahlberg O, Soderstrom H, Rastam M, Gillberg C (2004). Bipolar disorder, schizophrenia, and other psychotic disorders in adults with childhood onset AD/HD and/or autism spectrum disorders. Journal of Neural Transmission, 111, 891-902.

. Stanton SJ, Beehner JC, Saini EK, Kuhn CM, Labar KS (2009). Dominance, politics, and physiology: voters' testosterone changes on the night of the 2008 United States presidential election. PLOS ONE, 4, e7543.

. Stefanis N, Thewissen V, Bakoula C, van Os J, Myin-Germeys I (2006). Hearing impairment and psychosis: a replication in a cohort of young adults. Schizophrenia Research, 85, 266-272.

- Stewart SH (1996). Alcohol abuse in individuals exposed to trauma: A critical review. Psychological Bulletin, 120, 83-112.

- Swinnen SG, Selten JP (2007). Mood disorders and migration: meta-analysis. British Journal of Psychiatry, 190, 6-10.

Tidey JW, Miczek KA (1996). Social defeat stress selectively alters mesocorticolimbic dopamine release: an in vivo micro dialysis study. Brain Research, 721, 140-149.

. Toulopoulou T, Picchioni M, Rijsdijk F et al. (2007). Substantial genetic overlap between neurocognition and schizophrenia: genetic modeling in twin samples. Archives of General Psychiatry, 64, 1348-1355.

. Varese F, Smeets F, Drukker M et al. (2012). Childhood adversities increase the risk of psychosis: a meta-analysis of patient-control, prospective- and cross-sectional cohort studies. Schizophrenia Bulletin, 38, 661-671.

. Veling W, Selten JP, Veen ND, et al (2006). Incidence of schizophrenia among ethnic minorities in the Netherlands: a four-year first-contact study. Schizophrenia Research, 86, 189-193.

. Veling W, Susser E, van Os J, Mackenbach JP, Selten JP, Hoek HW (2008). Ethnic density of neighborhoods and incidence of psychotic disorders among immigrants. America Journal of Psychology, 165, 66-73.

de Waal F (2009). The age of empathy. Nature's lessons for a kinder society. Three Rivers Press, New York.

van der Werf M, Thewissen V, Dominguez MD, Lieb R, Wittchen H, van Os J (2011).

Adolescent development of psychosis as an outcome of hearing impairment: a 10-year longitudinal study. Psychological Medicine, 43, 477-485.

Zammit S, Allebeck P, David AS et al. (2004). A longitudinal study of pre-morbid IQ score and risk of developing schizophrenia, bipolar disorder, severe depression, and other non-affective psychoses. Archives of General Psychiatry, 61, 354-360. 


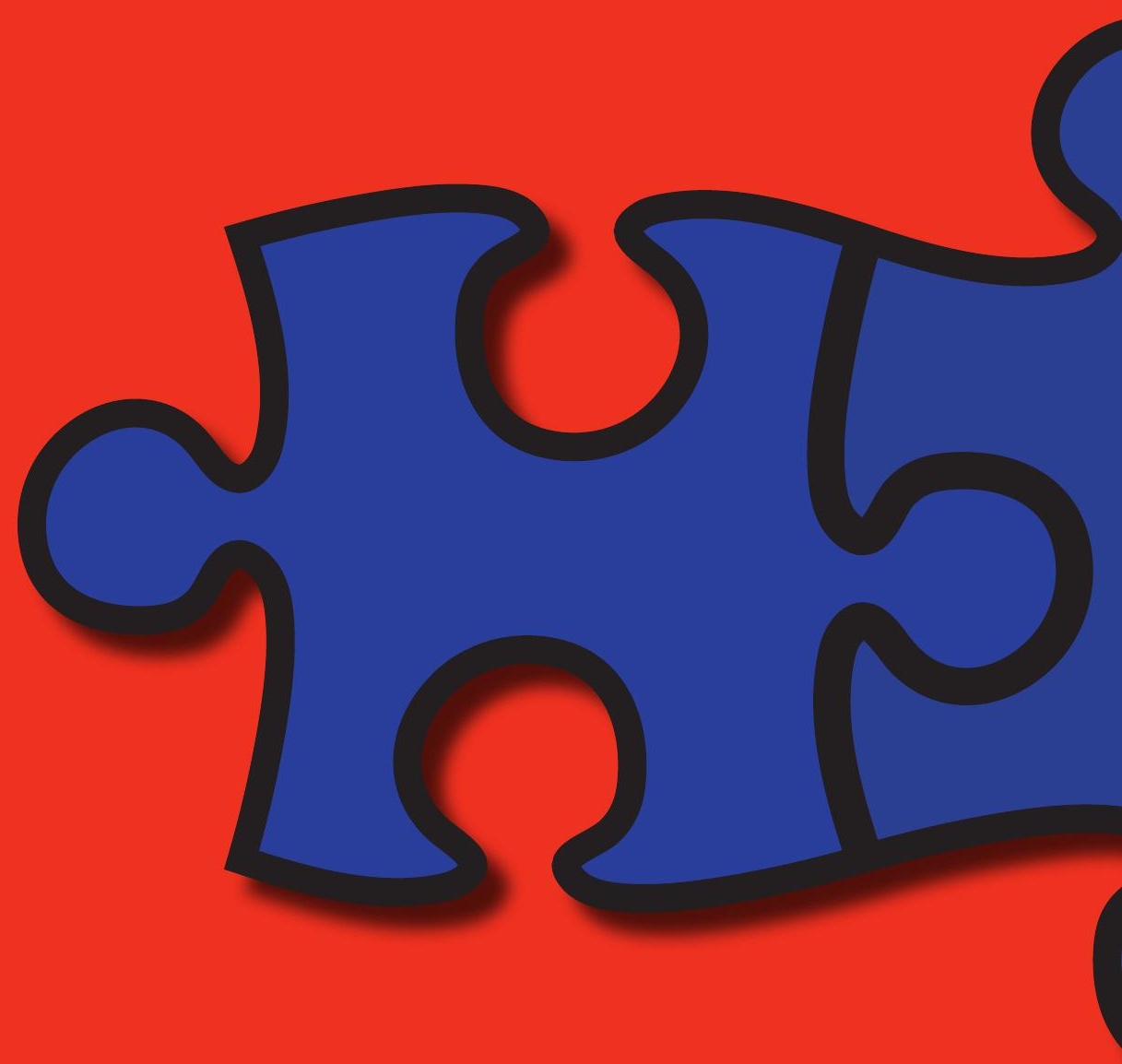

